\title{
Chinese Mustard Cultivation Guide for Florida ${ }^{1}$
}

\author{
Yuheng Qiu, Mary Dixon, and Guodong Liu
}

\section{General Description}

Chinese mustard (Brassica juncea (L.) Czern) is a nutritious leafy vegetable in the family Brassicaceae. The nomenclature for Chinese mustard is diverse; there are various Latin binomials with synonyms including Brassica japonica (Thunb.) Siebold ex Miq. (CABI 2019, Fern 2020). Chinese mustard also goes by many common names, such as brown mustard, mustard greens, leaf mustard, Indian mustard, Oriental mustard, and vegetable mustard (https://npgsweb. ars-grin.gov/gringlobal/taxon/taxonomydetail?id=7654, CABI 2019, Cornell 2006, Fern 2020, Purdue 2020). The origin of Chinese mustard is likely Central Asia with subsequent migrations to India and China (CABI 2019, Chen et al. 2013). Chinese mustard is widely distributed in areas where annual mean temperature is greater than $43^{\circ} \mathrm{F}$, and it has been introduced to all 50 US states (CABI 2019, USDA-NRCS 2020). Although it is considered a weed in a few states, such as Michigan, this species is not listed as invasive in Florida and has been cultivated in several counties, including Levy, Palm Beach, and Miami-Dade (USDA-NRCS 2020).

\section{Botanical Description}

Chinese mustard is a perennial herb, but growers often cultivate the plant as an annual or biennial (CABI 2019, Fern 2020, Purdue 2020). This plant can grow up to 2 to 3 feet tall (CABI 2019, Cornell 2006), with erect stems and branches (CABI 2019, Fern 2020, Purdue 2020) (Figure 1, Figure 2). The green-to-purple leaves have flat veins and an ovate shape with toothed margins, and the marketable size of a plant leaf is usually measured at least 6 inches in both length and width (CABI 2019, NCSU Extension 2020, Purdue 2020) (Figure 3). Each flower has typically four petals, creating a cruciform, or cross-like, shape (Castner 2004, NCSU Extension 2020). The petals are small, 0.25 to 0.5 inches in length and 0.2 to 0.3 inches in width, and usually have an ovate shape with a narrow basal claw and yellow color (CABI 2019, Castner 2004). Roots of Chinese mustard plant can reach 3 to 4 feet deep (Purdue 2020).

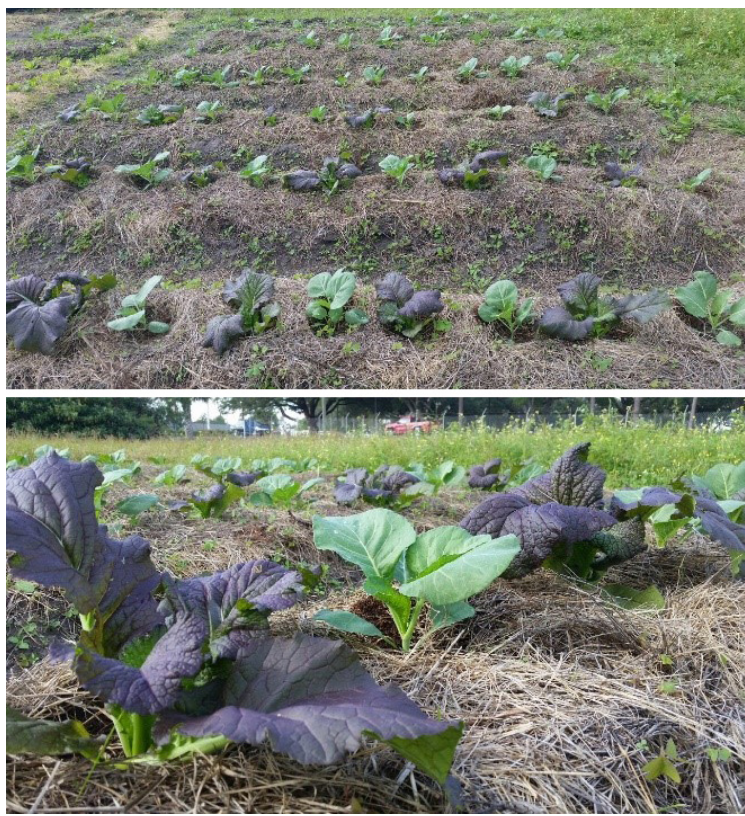

Figure 1. Chinese mustard 'Red Giant' (purple) (Brassica juncea (L.) Czern) interplanted with collard greens (green) (Brassica oleracea var. viridis L.).

Credits: Mary Dixon, UF/IFAS

1. This document is HS1402, one of a series of the Horticultural Sciences Department, UF/IFAS Extension. Original publication date January 2021. Visit the EDIS website at https://edis.ifas.ufl.edu for the currently supported version of this publication.

2. Yuheng Qiu, OPS Technical, MS; Mary Dixon, graduate student; Guodong Liu, associate professor, Horticultural Sciences Department; UF/IFAS Extension, Gainesville, FL 32611.

The Institute of Food and Agricultural Sciences (IFAS) is an Equal Opportunity Institution authorized to provide research, educational information and other services

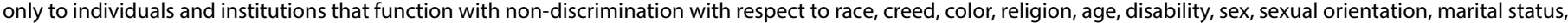

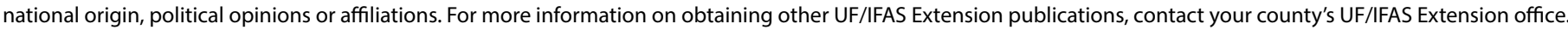
U.S. Department of Agriculture, UF/IFAS Extension Service, University of Florida, IFAS, Florida A \& M University Cooperative Extension Program, and Boards of County Commissioners Cooperating. Nick T. Place, dean for UF/IFAS Extension. 


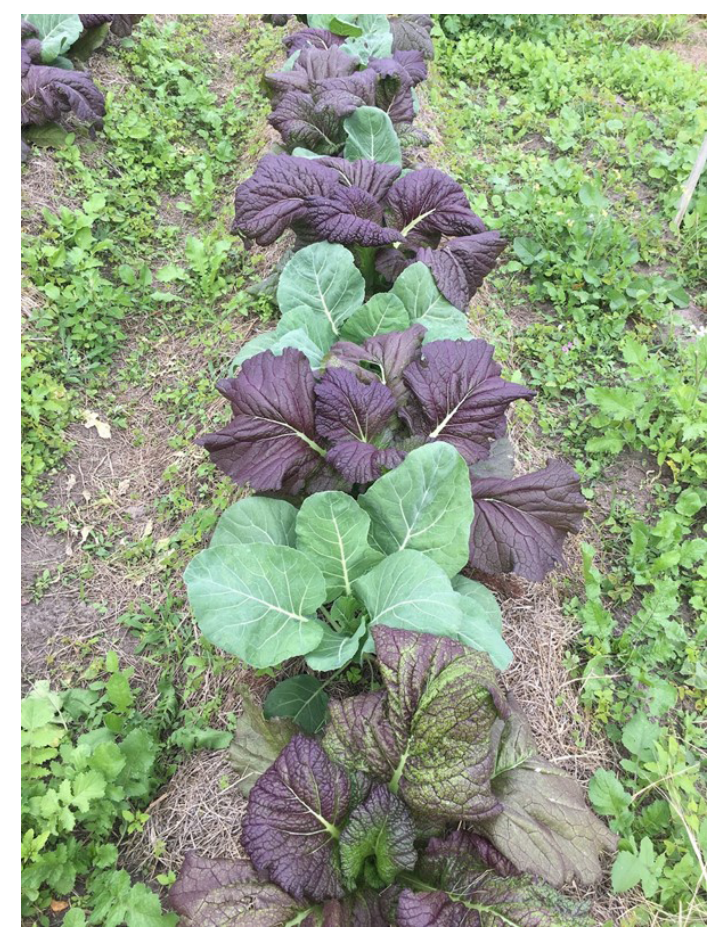

Figure 2. Chinese mustard 'Red Giant' (purple) (Brassica juncea (L.) Czern) interplanted with collard greens (green) (Brassica oleracea var. viridis L.).

Credits: Mary Dixon, UF/IFAS

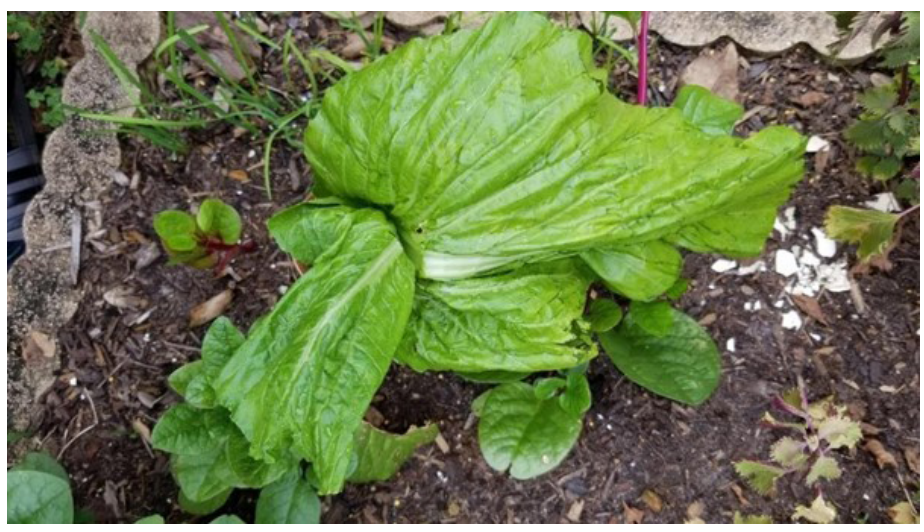

Figure 3. Chinese mustard (Brassica juncea (L.) Czern) marketable leaves.

Credits: Guodong Liu, UF/IFAS

\section{Propagation}

Chinese mustard seeds are tiny, globose-shaped, and usually brown or yellow in color (CABI 2019). Seeds may be sown a quarter to a half inch deep and spaced 4 to 8 inches between adjacent plants in rows 12 to 16 inches apart (Anderson 2011, Brown et al. 2018, Drost and Johnson 2020). Chinese mustard is a cool-season vegetable crop, and it requires 3 to 7 days to emerge after seeding (Masabni 2014). Plant germination will stagnate if the temperature is higher than $85^{\circ} \mathrm{F}$ or lower than $40^{\circ} \mathrm{F}$ (Cornell 2006, Drost and Johnson 2020). The planting date of Chinese mustard in Florida depends on location (Brown et al. 2018) (Table 1).

\section{Cultivation Practices}

Chinese mustard grows optimally in full-sun conditions (Anderson 2011, Cornell 2006), but partial shade may be beneficial for the crop during warm weather (Cornell 2006). Varieties recommended for Florida cultivation include 'Southern Giant Curled' and 'Florida Broad Leaf' (UF/IFAS Master Gardener Program 2020).

Chinese mustard requires consistent moisture through irrigation, especially during dry periods, to prevent slow development and off flavors (Cornell 2006, Drost and Johnson 2020). This vegetable can tolerate mean annual rainfall up to 160 inches (CABI 2019, Fern 2020, Anderson 2011, UIUC Extension 2020). When temperature is higher than $85^{\circ} \mathrm{F}$, Chinese mustard might bolt quickly and develop leaf bitterness due to the lack of moisture (Cornell 2006, MSU Extension 2020).

Chinese mustard grows optimally in well-drained fertile soils with a pH of 6.0 to 7.5 (Cornell 2006, Fern 2020). The crop can tolerate slightly acidic and alkaline soil (Cornell 2006, Purdue 2020). The UF/IFAS recommendations of NPK are available for mustard but not Chinese mustard grown in Florida. Because Chinese mustard and mustard belong to the same family, growers can employ the current mustard recommendations for Chinese mustard: $120 \mathrm{lb} /$ ac of $\mathrm{N}$, and 0,100 , or $120-150 \mathrm{lb} / \mathrm{ac}$ of either $\mathrm{P}_{2} \mathrm{O}_{5}$ or $\mathrm{K}_{2} \mathrm{O}$ for high, medium, and low soil test indices with the Mehlich-3 soil extractant method. Please see Chapter 2. Fertilizer Management for Vegetable Production in Florida in the Vegetable Production Handbook of Florida (available at https://edis.ifas.ufl.edu/cv296, Liu et al. 2020).

\section{Pests and Diseases}

Chinese mustard has relatively high resistance to pests and diseases compared to other cole crops, such as cabbage and cauliflower (Cornell 2006). However, there are still several pests that might cause deleterious effects to the crop. Therefore, an integrated pest management approach is critical to successful Chinese mustard production. For chemical control recommendations, please see Chapter 6. Cole Crop Production in the Vegetable Production Handbook of Florida (available at https://edis.ifas.ufl.edu/cv122).

For overarching pest and disease control, remove infected plants immediately to prevent spread (Smith 2007). Also, floating row covers can help minimize early-season infestation (Cornell 2006). Chinese mustard is host to pests including aphids (Aphis spp.), flea beetles (Altica spp.), and whiteflies (Aleyrodidae spp.) (Anderson 2011, Cornell 2006). Intercropping with alyssum (Lobularia maritima (L.) 
Desv.) effectively controls aphid and whitefly populations in other cole crops such as broccoli (Brassica oleracea $\mathrm{L}$. var. italica Plenck) (Brennan 2016) and collard greens (Brassica oleracea L. var. acephala) (Ribeiro and Gontijo 2017) by attracting hoverflies, a natural aphid predator, and coccinellids, a natural whitefly predator. Botanical extracts of Zingiber officinale at $25 \% \mathrm{w} / \mathrm{v}$ has been shown to reduce incidence of flea beetle damage in cole crops such as cabbage (Brassica oleracea L. var. sabauda) (Foluke 2017). Several cabbage worms, such as imported cabbageworms (Pieris rapae L.), cabbage loopers (Trichoplusia ni Hübner), and diamondback moth worms (Plutella xylostella L.), can also pose a threat to the plant by attacking the leaves (UIUC Extension 2020). Bioinsecticides utilizing the entomopathogenic fungi Beauveria bassiana have been shown to control cabbageworm populations in cabbage (Garcia-Gutierrez et al. 2009).

Chinese mustard may be susceptible to diseases, particularly downy mildew (Hyaloperonospora parasitica (Pers.) Constant), which results in a misshapen leaf with yellow blotches (Smith 2007, UIUC Extension 2020). Seed treatment and later foliar spray of Allium sativum bulb extract at $1 \% \mathrm{w} / \mathrm{v}$ may reduce the severity and incidence of downy mildew, Alternaria leaf blight (Alternaria brassicae (Berk.) Sacc.), white rust (Albugo candida (Pers. Ex Lev.) Kuntze), Sclerotinia rot (Sclerotinia sclerotiorum (Lib.) de Bary), and powdery mildew (Erysiphe cruciferarum Opiz ex L. Junell) on Chinese mustard (Meena et al. 2013).

\section{Harvest and Storage}

Chinese mustard grows fast, and recommended varieties such as 'South Giant Curled', and 'Florida Broad Leaf' usually reach harvest maturity 45 to 50 days after planting (Cornell 2006). This crop can be harvested by either cutting the entire plant or picking off the fully expanded leaves (Anderson 2011, MSU Extension 2020, UIUC Extension 2020). For successive harvesting, cutting off only the plant crowns allows plants to regrow for a second harvest (MSU Extension 2020). While harvesting, avoid unmarketable dead, yellowing, and overmatured leaves (UIUC Extension 2020). Because cloudy weather might decrease leaf vitamin $\mathrm{C}$ and mineral nutrients, it is recommended to harvest the plant during the period of high light intensity within a short time period (Makus and Lester 2004). Fresh Chinese mustard can be stored in the refrigerator for three days when put in plastic bags (UIUC Extension 2020). Plants may be stored up to five days if leaves are wrapped in moist paper towels (UIUC Extension 2020). Chinese mustard can stay fresh for 12 days if stored in vacuum bags at temperatures of $34^{\circ} \mathrm{F}-38^{\circ} \mathrm{F}$ but will quickly decay if temperature rises above $59^{\circ} \mathrm{F}$ (Bracy 1990).

\section{Uses}

Chinese mustard leaves can be either eaten raw, in salad mixes, stir-fried, or braised with ham, pork, or turkey (Purdue 2020, UIUC Extension 2020) (Figure 4). This vegetable is nutritious and rich in vitamins (e.g., vitamins A, C, and K), carotene, and minerals (e.g., Ca and K) (Table 2) (UIUC Extension 2020). Chinese mustard can also be cultivated as an oil-yielding crop; its seeds contain $30 \%$ to $45 \%$ oil and are a primary source for canola oil (CABI 2019, Purdue 2020).

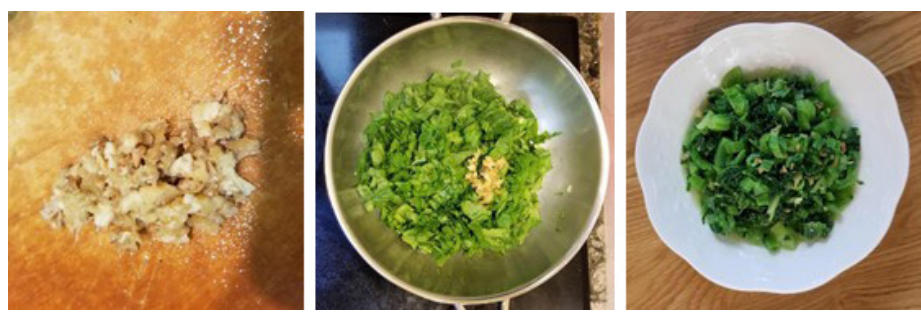

Figure 4. Chinese mustard (Brassica juncea (L.) Czern) and finely chopped ginger root served in soup (left), in salad mixes (middle), and stir-fried with oil (right).

Credits: Guodong Liu, UF/IFAS

Because Chinese mustard is a good source of antioxidants such as beta carotene and vitamin C (Table 2) (USDA-ARS 2019), consumption may help protect against free radicals and oxidative-related diseases (Frazie et al. 2017, Lin and Harnly 2010, Pham-Huy et al. 2008). Also, Chinese mustard might be good for the immune system due to high vitamin A and C concentrations (Carr and Maggini 2017, Huang et al. 2018). Being rich in vitamin $\mathrm{K}$ makes this vegetable good for bone health as well (DiNicolantonio et al. 2015). Chinese mustard is beneficial for heart and eye health due to the presence of flavonoids, beta carotene (Ciccone et al. 2013, Rees et al. 2018), lutein, and zeaxanthin (Buscemi et al. 2018, Jia et al. 2017). In addition, this plant contains glucosinolates, which are effective in the treatment of microbial infection and fighting against cancer (Becker and Juvik 2016, Frazie et al. 2017, Melrose 2019) (Table 2).

Chinese mustard has potential to treat heavy metal pollution by phytoremediation (CABI 2019); it has been found to significantly decrease the level of cadmium, copper, lead, and zinc in soil (Bauddh and Singh 2011, Lim et al. 2004, Salido et al. 2010, Singh and Fulekar 2012, Turan and Esringü 2007). Also, Chinese mustard is a good biological control agent for pathogenic nematodes (Globodera pallida) because it significantly reduces nematode reproduction (Ngala et al. 2015, Zasada and Ferris 2004), which may make this crop a good candidate for crop rotation. Chinese 
mustard is rich in glucosinolates; incorporating residuals may have an effect as a biofumigant to control soilborne issues and decrease nematode population (Henderson et al. 2009, Salem and Mahdy 2015).

\section{Marketability and Future Outlook}

Chinese mustard has been widely cultivated in the United States due to its high nutritional and medicinal values (USDA-NRCS 2020). According to the University of Kentucky Cooperative Extension Service and University of Arkansas Cooperative Extension Service, the estimated expenses for growing Chinese mustard would be $\$ 3,000$ to $\$ 3,500$ per acre (Kaiser and Ernst 2017, Sanders 2015), which generates an approximate $\$ 1,000$ to $\$ 1,500$ profit (Sanders 2015). Leafy greens that are used in salads and sandwiches are consumed daily by many US consumers, and many are motivated to try other nontraditional leafy vegetables (Kaiser and Ernst 2017). Chinese mustard offers many advantages, such as a distinct peppery and nutty flavor often preferred by consumers, in addition to a high nutritional value (UF/IFAS Gardening Solutions 2020). If marketed properly, Chinese mustard could be a new cash crop in Florida.

\section{Acknowledgments}

Professor emeritus Dr. Edward Hanlon at the University of Florida reviewed the manuscript.

\section{References}

Anderson, C. R. 2011. Mustard Greens. FSA6072. Fayetteville: University of Arkansas Division of Agriculture. Accessed on August 10, 2020. https://www.uaex.edu/ publications/PDF/FSA-6072.pdf

Bauddh, K., and R. P. Singh. 2012. "Cadmium tolerance and its phytoremediation by two oil yielding plants Ricinus communis (L.) and Brassica juncea (L.) from the contaminated soil." International Journal of Phytoremediation 14 (8): 772-785.

Becker, T. M., and J. A. Juvik. 2016. "The role of glucosinolate hydrolysis products from Brassica vegetable consumption in inducing antioxidant activity and reducing cancer incidence." Diseases 4 (2): 22.
Bracy, R. P. 1990. "Influence of storage temperature and duration on deterioration of film-wrapped and nonwrapped mustard, Brassica juncea Coss." LSU Historical Dissertations and Theses 4897. https://digitalcommons.lsu. edu/gradschool_disstheses/4897/

Brennan, E. B. 2016. "Agronomy of strip intercropping broccoli with alyssum for biological control of aphids." Biological Control 97:109-119.

Brown, S. P., D. Treadwell, J. M. Stephens, and S. Webb. 2018. Florida Vegetable Gardening Guide. SP103.

Gainesville: University of Florida Institute of Food and Agricultural Sciences. https://edis.ifas.ufl.edu/vh021

Buscemi, S., D. Corleo, F. Di Pace, M. L. Petroni, A. Satriano, and G. Marchesini. 2018. "The effect of lutein on eye and extra-eye health." Nutrients 10 (9): 1321.

CABI. 2019. “Brassica juncea (Mustard)." Invasive Species Compendium. Wallingford, UK: CAB International. Accessed on August 10, 2020. https://www.cabi.org/isc/ datasheet $/ 91760$

Carr, A. C., and S. Maggini. 2017. "Vitamin C and immune function." Nutrients 9 (11): 1211.

Castner, J. L. 2004. “Brassicaceae - Mustard Family." In Photographic Atlas of Botany and Guide to Plant Identification, 214-215. Gainesville, FL: Feline Press.

Chen, S., Z. Wan, M. N. Nelson, J. S. Chauhan, R. Redden, W. A. Burton, P. Lin, P. A. Salisbury, T. Fu, and W. A. Cowling. 2013. "Evidence from genome-wide simple sequence repeat markers for a polyphyletic origin and secondary centers of genetic diversity of Brassica juncea in China and India." Journal of Heredity 104 (3): 416-427.

Ciccone, M. M., F. Cortese, M. Gesualdo, S. Carbonara, A. Zito, G. Ricci, F. D. Pascalis, P. Scicchitano, and G. Riccioni. 2013. "Dietary intake of carotenoids and their antioxidant and anti-inflammatory effects in cardiovascular care." Mediators of Inflammation 2013:782137.

Cornell University. 2006. "Explore Cornell: Home gardening flower growing guides." Cornell University Home Gardening. Accessed on August 10, 2020. http://www. gardening.cornell.edu/homegardening/scene2b9a.html 
Di Nicolantonio, J. J., J. Bhutani, and J. H. O’Keefe. 2015. "The health benefits of vitamin K." Open Heart 2 (1): e000300.

Drost, D., and M. Johnson. 2020. "Mustard in the Garden." Utah State University Extension. Accessed on August 19, 2020. https://digitalcommons.usu.edu/cgi/viewcontent.cgi? article $=1675 \&$ context $=$ extension_curall

Fern, K. 2020. “Brassica juncea (L.) Czern.” Tropical Plants Database. Accessed on August 10, 2020. http://tropical. theferns.info/viewtropical.php?id=Brassica+juncea

Foluke, O. A. 2017. "Efficacy of botanical insecticides in control of flea beetle (Phyllotreta cruciferae) on cabbage (Brassica oleracea Linn) on field." Journal of Northeast Agricultural University 3:30-36.

Frazie, M. D., M. J. Kim, and K. M. Ku. 2017. "Healthpromoting phytochemicals from 11 mustard cultivars at baby leaf and mature stages." Molecules 22 (10): 1749.

Garcia-Gutierrez, C., N. M. Rosas-Garcia, M. NorzagarayCampos, and I. Chairez-Hernandez. 2009. "Efficacy of Beauveria bassiana and Metarhizium anisoplia to control Pieris rapae on cabbage in the field." Southwestern Entomologist 35 (1): 75-83.

Henderson, D. R., E. Riga, R. A. Ramirez, J. Wilson, and W. E. Snyder. 2009. "Mustard biofumigation disrupts biological control by Steinernema spp. nematodes in the soil." Biological Control 48 (3): 316-322. https://doi.org/10.1016/j. biocontrol.2008.12.004

Huang, Z., Y. Liu, G. Qi, D. Brand, and S. G. Zheng. 2018. "Role of vitamin A in the immune system." Journal of Clinical Medicine 7 (9): 258.

Jia, Y. P., L. Sun, H. S. Yu, L. P. Liang, W. Li, H. Ding, X. B. Song, and L. J. Zhang. 2017. "The pharmacological effects of lutein and zeaxanthin on visual disorders and cognition diseases." Molecules 22 (4): 610.

Kaiser, C., and M. Ernst. 2017. Leafy Greens. CCD-CP-103. Lexington, KY: Center for Crop Diversification, University of Kentucky College of Agriculture, Food and Environment. Accessed on August 13, 2020. https://www.uky.edu/ccd/ sites/www.uky.edu.ccd/files/leafygreens.pdf
Lim, J. M., A. L. Salido, and D. J. Butcher. 2004. "Phytoremediation of lead using Indian mustard (Brassica juncea) with EDTA and electrodics." Microchemical Journal 76 (1-2): 3-9.

Lin, L. Z., and J. M. Harnly. 2010. "Phenolic component profiles of mustard greens, yu choy, and 15 other Brassica vegetables." Journal of Agricultural and Food Chemistry 58 (11): 6850-6857.

Liu, G. D., E. H. Simonne, K. T. Morgan, G. J. Hochmuth, S. Agehara, and R. Mylavarapu. 2020. "Chapter 2. Fertilizer Management for Vegetable Production in Florida." CV296. In Vegetable Production Handbook of Florida, edited by P. J. Dittmar, J. H. Freeman, M. L. Paret, and H. A. Smith. 3-14. Gainesville: University of Florida Institute of Food and Agricultural Sciences. https://edis.ifas.ufl.edu/cv296

Makus, D. J., and G. Lester. 2004. "Light intensity and time of day at harvest affects ascorbic acid concentration and mineral nutrient content and leaf greenness in field-grown mustard greens." Subtropical Plant Science 56:21-25.

Masabni, J. 2014. "Growing turnip and mustard greens." Texas A\&M AgriLife Extension. Accessed on October 8, 2020. https://cdn-ext.agnet.tamu.edu/wp-content/uploads/2014/09/how-to-grow-turnip-greens-and-mustardgreens.pdf

Meena, P. D., R. B. Gour, J. C. Gupta, H. K. Singh, R. P. Awasthi, R. S. Netum, S. Godika, P. S. Sandhu, R. Prasad, A. S. Rathi, D. Rai, L. Thomas, G. A. Patel, and C. Chattopadhyay. 2013. "Non-chemical agents provide tenable, eco-friendly alternatives for the management of the major diseases devastating Indian mustard (Brassica juncea) in India." Crop Production 53:169-174.

Melrose, J. 2019. “The glucosinolates: A Sulphur glucoside family of mustard anti-tumor and antimicrobial phytochemicals of potential therapeutic application." Biomedicines 7 (3): 62 .

Mississippi State University. 2020. "Mustard Greens.” Mississippi State University Extension. Accessed on August 10, 2020. http://extension.msstate.edu/ vegetable-gardening-mississippi/vegetable-varieties/ mustard-greens 
Ngala, B. M., P. P. Haydock, S. Woods, and M. A. Back. 2015. "Biofumigation with Brassica juncea, Raphanus sativus and Eruca sativa for the management of field populations of the potato cyst nematode Globodera pallida." Pest Management Science 71 (5): 759-769.

North Carolina State University. 2020. "Brassica juncea." North Carolina Extension Gardener Plant Toolbox. Accessed October 8, 2020. https://plants.ces.ncsu.edu/plants/ brassica-juncea/

Pham-Huy, L. A., H. He, and C. Pham-Huy. 2008. "Free radicals, antioxidants in disease and health." International Journal of Biomedical Science: IJBS 4 (2): 89.

Rees, A., G. F. Dodd, and J. P. Spencer. 2018. "The effects of flavonoids on cardiovascular health: A review of human intervention trials and implications for cerebrovascular function." Nutrients 10 (12): 1852.

Ribeiro, A. L., and L. M. Gontijo. 2017. "Alyssum flowers promote biological control of collard pests." BioControl 62:185-196.

Salem, M. F., and M. E. Mahdy. 2015. "Suppression of rootknot nematode through innovative mustard biofumigation." Future of Food: Journal on Food, Agriculture and Society 3 (2): 41-50.

Salido, A. L., K. L. Hasty, J. M. Lim, and D. J. Butcher. 2003. "Phytoremediation of arsenic and lead in contaminated soil using Chinese brake ferns (Pteris vittata) and Indian mustard (Brassica juncea)." International Journal of Phytoremediation 5 (2): 89-103.

Sanders, C. 2015. "Fall greens may be an alternative for small farmers." University of Arkansas Extension. Accessed on August 13, 2020. https://www.uaex.edu/media-resources/news/september2105/09-04-2015-Ark-fall-greens.aspx

Singh, A., and M. H. Fulekar. 2012. "Phytoremediation of heavy metals by Brassica juncea in aquatic and terrestrial environment." The Plant Family Brassicaceae 21:153-169.
Smith, S. 2007. Diseases of Turnip and Mustard Greens. FSA7549. Fayetteville: University of Arkansas Division of Agriculture. Accessed on August 10, 2020. https://www. uaex.edu/publications/PDF/FSA-7549.pdf

Turan, M., and A. Esringü. 2007. "Phytoremediation based on canola (Brassica napus L.) and Indian mustard (Brassica juncea $\mathrm{L}$.) planted on spiked soil by aliquot amount of $\mathrm{Cd}$, $\mathrm{Cu}, \mathrm{Pb}$, and Zn." Plant Soil and Environment 53 (1): 7-15.

UF/IFAS Gardening Solutions. 2020. Greens. Gainesville: University of Florida Institute of Food and Agricultural Sciences. Accessed on August 13, 2020. https://gardeningsolutions.ifas.ufl.edu/plants/edibles/vegetables/greens.html

UF/IFAS Master Gardener Program. 2011. The Neighborhood Gardener: Five Fall Vegetables for the Home Garden. Gainesville: University of Florida Institute of Food and Agricultural Sciences. Accessed on October 8, 2020. https:// gardeningsolutions.ifas.ufl.edu/mastergardener/newsletter/2009/more/fall_vegetables.shtml

University of Illinois Urbana-Champaign. 2020. "Watch your garden grow." University of Illinois Extension. Accessed on August 10, 2020. https://web.extension.illinois.edu/ veggies/mustard.cfm

USDA-ARS. 2019. "National Nutrient Database for Standard Reference, Full Report (All Nutrients) 11270, Mustard greens (Brassica juncea (L.) Czern.), raw." Accessed on August 10, 2020. https://fdc.nal.usda.gov/fdc-app.html\#/ food-details/169256/nutrients

USDA-NRCS. 2020. "PLANTS profile for Brassica juncea (L.) Czern. (Brown mustard)." The PLANTS Database. National Plant Data Team, Greensboro, NC 27401-4901 USA. Accessed on August 10, 2020. https://plants.usda.gov/ core/profile? symbol=BRJU

Zasada, I. A., and H. Ferris. 2004. "Nematode suppression with brassicaceous amendments: Application based upon glucosinolate profiles." Soil Biology and Biochemistry 36 (7): 1017-1024. 
Table 1. Florida outdoor planting dates for Chinese mustard. Source: https://edis.ifas.ufl.edu/vh021

\begin{tabular}{|l|l|l|l|}
\hline \multirow{2}{*}{ Crop } & \multicolumn{3}{|c|}{ Florida Outdoor Planting Date } \\
\cline { 2 - 4 } & North (of State Road 40) & Central (between State Road 40 and 70) & South (of State Road 70) \\
\hline Chinese Mustard & August-February & September-February & September-January \\
\hline
\end{tabular}

Table 2. Nutritional value of Chinese mustard (Brassica juncea (L.) Czern.), raw, per 100 g. Source: USDA-ARS, National Nutrient Database available at: https://fdc.nal.usda.gov/fdc-app.html\#/food-details/169256/nutrients

\begin{tabular}{|c|c|c|}
\hline Name & Amount & Unit \\
\hline \multicolumn{3}{|l|}{ Variables } \\
\hline Water & 90.7 & $g$ \\
\hline Energy & 27 & kcal \\
\hline Energy & 114 & $\mathrm{~kJ}$ \\
\hline Protein & 2.86 & $\mathrm{~g}$ \\
\hline Total lipid (fat) & 0.42 & $g$ \\
\hline Ash & 1.36 & $g$ \\
\hline Carbohydrate, by difference & 4.67 & $\mathrm{~g}$ \\
\hline Fiber, total dietary & 3.2 & $g$ \\
\hline Sugars, total including NLEA & 1.32 & $g$ \\
\hline \multicolumn{3}{|l|}{ Minerals } \\
\hline Calcium, Ca & 115 & $\mathrm{mg}$ \\
\hline Copper, Cu & 0.165 & $\mathrm{mg}$ \\
\hline Iron, Fe & 1.64 & $\mathrm{mg}$ \\
\hline Magnesium, Mg & 32 & $\mathrm{mg}$ \\
\hline Phosphorus, P & 58 & $\mathrm{mg}$ \\
\hline Potassium, $\mathrm{K}$ & 384 & $\mathrm{mg}$ \\
\hline Selenium, Se & 0.9 & $\mu \mathrm{g}$ \\
\hline Sodium, $\mathrm{Na}$ & 20 & $\mathrm{mg}$ \\
\hline Zinc, Zn & 0.25 & $\mathrm{mg}$ \\
\hline \multicolumn{3}{|l|}{ Vitamins } \\
\hline Vitamin A, IU & 3024 & IU \\
\hline Vitamin A, RAE & 151 & $\mu \mathrm{g}$ \\
\hline Vitamin B-6 & 0.18 & $\mathrm{mg}$ \\
\hline Vitamin B-12 & 0 & $\mu \mathrm{g}$ \\
\hline Vitamin B-12, added & 0 & $\mu \mathrm{g}$ \\
\hline Vitamin C, total ascorbic acid & 70 & $\mathrm{mg}$ \\
\hline Vitamin D (D2 + D3) & 0 & $\mu g$ \\
\hline Vitamin D (D2 + D3), International Units & 0 & IU \\
\hline Vitamin E (alpha-tocopherol) & 2.01 & $\mathrm{mg}$ \\
\hline Vitamin E, added & 0 & $\mathrm{mg}$ \\
\hline Vitamin K (phylloquinone) & 257.5 & $\mu \mathrm{g}$ \\
\hline Folate, total & 12 & $\mu \mathrm{g}$ \\
\hline Folic acid & 0 & $\mu \mathrm{g}$ \\
\hline Folate, food & 12 & $\mu \mathrm{g}$ \\
\hline Folate, DFE & 12 & $\mu \mathrm{g}$ \\
\hline Carotene, alpha & 10 & $\mu \mathrm{g}$ \\
\hline Carotene, beta & 1790 & $\mu g$ \\
\hline Choline, total & 0.5 & $\mathrm{mg}$ \\
\hline
\end{tabular}




\begin{tabular}{|l|c|c|}
\hline \multicolumn{1}{|c|}{ Name } & Amount & Unit \\
\hline Cryptoxanthin, beta & 40 & $\mu \mathrm{g}$ \\
\hline Lycopene & 0 & $\mu \mathrm{g}$ \\
\hline Lutein + zeaxanthin & 3730 & $\mu \mathrm{g}$ \\
\hline Niacin & 0.8 & $\mathrm{mg}$ \\
\hline Pantothenic acid & 0.21 & $\mathrm{mg}$ \\
\hline Retinol & 0 & $\mathrm{mg}$ \\
\hline Riboflavin & 0.11 & $\mathrm{mg}$ \\
\hline Thiamin & 0.08 & $\mathrm{mg}$ \\
\hline Lipids & & $\mathrm{mg}$ \\
\hline Cholesterol & 0 & $\mathrm{~g}$ \\
\hline Fatty acids, total saturated & 0.01 & $\mathrm{~g}$ \\
\hline Fatty acids, total monounsaturated & 0.092 & $\mathrm{~g}$ \\
\hline Fatty acids, total polyunsaturated & 0.038 & $\mathrm{~g}$ \\
\hline Fatty acids, total trans & 0 & $\mathrm{~g}$ \\
\hline Others & & $\mathrm{mg}$ \\
\hline Alcohol, ethyl & 0 & $\mathrm{mg}$ \\
\hline Caffeine & 0 & \\
\hline Theobromine & 0 & \\
\hline
\end{tabular}

